\title{
PERLINDUNGAN HUKUM TERHADAP KORBAN SALAH TANGKAP DALAM TINDAK PIDANA MENURUT KUHAP
}

\author{
Oleh \\ Prasetyo Margono \\ Dosen Fakultas Hukum Universitas Islam Lamongan
}

\begin{abstract}
ABSTRAK
Hukum pada dasarnya tidak dapat dipisahkan dari kehidupan manusia, di mulai dari sejak kita dalam kandungan sampai kita mati semuanya sudah diatur oleh hukum. Proses Pidana yang dibahas dalam tulisan ini adalah tentang penangkapan yang eror in persona (kesalahan mengenai orangnya) dalam hal ini tidak lepas dari tahapan-tahapan penangkapan, pemeriksaan tersangka pada tingkat penyidikan. Dalam Pasal 1 butir 5 KUHAP menyebutkan penyelidikan adalah serangkaian tindakan penyelidik untuk mencari dan menemukan suatu peristiwa yang diduga sebagai tindak pidana guna menentukan dapat atau tidaknya dilakukan penyidikan menurut cara yang diatur UndangUndang ini.

Berdasarkan uraian latar belakang masalah diatas, dapatlah dirumuskan beberapa permasalahan yaitu bagaimanakah prosedur penangkapan dalam tindak pidana dan bagaimana perlindungan hukum terhadap korban salah tangkap menurut KUHAP. Tipe penelitian hukum yang dilakukan adalah Yuridis Normatif. Penelitian hukum ini difokuskan untuk mengkaji penelitian hukum tentang kaidah-kaidah atau norma-norma dalam hukum positif. Pendekatan yang digunakan adalah pendekatan Perundang-Undang (statute approach) pendekatan tersebut melakukan pengkajian terhadap Undang-Undang yang berhubungan dengan pokok permasalahan.
\end{abstract}

Kata kunci : Perlindungan Hukum Korban Salah Tangkap.

\section{PENDAHULUAN}

Hukum pada dasarnya tidak dapat dipisahkan dari kehidupan manusia, di mulai dari sejak kita dalam kandungan sampai kita mati semuanya sudah diatur oleh hukum. Manusia merasa terlindungi, hidup berdampingan secara damai dan menjaga eksistensinya di dunia menjadi peran sentral hukum dalam sepanjang sejarah peradaban manusia. Pasal 1 ayat (3) Undang-Undang Dasar Negara Republik Indonesia Tahun 1945 telah jelas menegaskan bahwa Negara kita adalah Negara hukum. Hal ini berarti bahwa Indonesia harus menjunjung tinggi hukum serta dalam tindakannya harus didasarkan pada hukum atau peraturan yang diciptakan untuk mengatur warga Negaranya dan juga tatanan di dalam Pemerintahan.

Ketentuan-ketentuan di dalam Undang-Undang nomor 8 tahun 1981 tentang Hukum Acara Pidana yang lazim di sebut dengan KUHAP adalah merupakan realisasi dari asas negara hukum yang mengatur ketentuan tentang cara proses pidana mulai dari tingkat Penyidikan, Penuntutan, dan Pengadilan dalam lingkungan peradilan umum yang di dalamnya mengatur hakhak dan kewajiban-kewajiban seseorang dalam proses Pidana. Proses Pidana yang dibahas dalam tulisan ini adalah tentang penangkapan yang eror in persona (kesalahan mengenai orangnya) dalam hal ini tidak lepas dari 
tahapan-tahapan

penangkapan, pemeriksaan tersangka pada tingkat penyidikan. Dalam Pasal 1 butir 5 KUHAP menyebutkan penyelidikan adalah serangkaian tindakan penyelidik untuk mencari dan menemukan suatu peristiwa yang diduga sebagai tindak pidana guna menentukan dapat atau tidaknya dilakukan penyidikan menurut cara yang diatur Undang-Undang ini. Dari uraian tersebut dapat di ketahui bahwa fungsi penyelidikan dilaksanakan sebelum dilakukan penyidikan untuk mengetahui dan menentukan peristiwa apa yang telah terjadi serta dituangkan dalm bentuk laporan yang nantinya merupakan dasar permulaan penyidikan.

Sedangkan dalam Pasal 1 butir 2 KUHAP penyidikan adalah serangkaian tindakan penyidik dalam hal dan menurut cara yang diatur dalam Undang-Undang ini untuk mencari serta mengumpulkan bukti yang dengan bukti itu membuat terang tentang tindak pidana yang terjadi dan guna menemukan tersangkanya.

Berdasarkan pada rumusan tersebut secara kongkrit dapat di katakan bahwa penyidikan dimulai sesudah terjadi suatu tindak pidana untuk mendapatkan keteranganketerangan tentang kebenaran terjadinya suatu tindak pidana, kapan tindak pidana itu dilakukan, dimana tindak pidana itu dilakukan, dengan apa tindakan pidana itu dilakukan, bagaimana tindak pidana itu dilakukan, mengapa tindak pidana itu dilakukan dan siapa pelakunya.

Tujuan utama penyidikan dalam KUHAP adalah untuk mencari dan mengumpulakn bukti telah terjadi suatu tindak pidana. Dalam Pasal 7 ayat (1) KUHAP dan Pasal 16 ayat (1) Undang-Undang nomor 2 tahun 2002 tentang Kepolisian Negara Republik Indonesia, yang menyebutkan bahwa wewenang penyidik karena kewajibannya adalah sebagai berikut: ${ }^{1}$

1. Menerima laporan atau pengaduan dari seseorang tentang tindak pidana.

2. Melakukan tindakan pertama di tempat terjadinya perkara.

3. Menyuruh berhenti seseorang tersangka dan memeriksa tanda pengenal diri tersangka.

4. Melakukan penangkapan, penahanan, penggeledahan, dan penyitaan.

5. Melakukan pemeriksaan dan penyitaan surat.

6. Mengambil sidik jari dan memotret seseorang.

7. Memanggil seseorang untuk didengar dan diperiksa sebagai tersangka atau saksi.

8. Mendatangkan ahli yang diperlukan dalam hubunganya dengan pemeriksaan perkara.

9. Mengadakan penghentian penyidikan.

10. Melakukan tindakan lain menurut Hukum yang bertanggung jawab.

Penyidik dalam melakukan penangkapan harus benar-benar memperhatikan ketentuan atau aturan hukum yang berlaku. Di dalam Pasal 17 KUHAP syarat-syarat yang harus dipenuhi penyidik dalam melakukan penagkapan yaitu seorang tersangka yang diduga keras melakukan tindak Pidana dan dugaan yang kuat itu harus didasarkan pada permulaan bukti yang cukup.

Pengertian dari bukti permulaan yang cukup adalah bukti permulaan untuk menduga adanya

\footnotetext{
${ }^{1}$ M Karjadi dan R Soesilo, Kitab Undang-undang Hukum Acara Pidana, Politeia, Bogor, 1998, hlm 
tindak pidana antara lain berupa laporan pengaduan, keterangan, dan barang bukti yang ditemukan ditempat kejadian perkara sebagaimana dimaksudkan dalam Pasal 17 jo Pasal 1 butir 14 KUHAP. Selanjutnya dalam penjelasan Pasal 17 KUHAP juga menunjukan bahwa penangkapan tidak boleh dilakukan secara sewenang-wenang melainkan hanya ditujukan kepada mereka yang betul-betul melakukan suatu tindak pidana dan hanya boleh dilakukan untuk satu kali 24 jam setelah itu harus sudah dilepas jika tidak cukup bukti.

Berdasarkan uraian tersebut diatas dapat terlihat bahwa penyidik diberi wewenang untuk menangkap seseorang, tetapi dalam realitasnya kadang kala terjadi kasus - kasus salah tangkap yang antara lain sebagai berikut:

1) Yudistira Akhmad, seorang pelajar kelas 1 SMA di Pandegelang Banten, warga Kenanga, Kampung Baru, terbaring lemah mendapat perawatan medis di Rumah Sakit Bedah Benggala, Kota Serang, Senin, 28 Maret 2016, dia menjadi korban salah tangkap Polsek Carita, saat mengejar pelaku pencurian sepeda motor di Menes Pandegelang. Korban di tembak Polisi dari jarak dekat pada bagian lengan kanan hingga tembus pada bagian belakang lengan kanan. ${ }^{2}$

2) Peristiwa Gorontalo pada tahun 2002 dimana sepasang suami istri yakni Risman Lakoro dan Rostin Mahaji disangka dan didakwa melakukan pembunuhan terhadap putri kandung mereka Alta Lakoro dan akhirnya

${ }^{2}$ https://m.tempo.co/read/video/2016/03/28/4259/pe lajar-korban-salah-tangkap-ini-ditembak-dandianiaya-polisi dijatuhi pidana 3 tahun penjara namun beberapa tahun kemudian setelah mereka selesai menjalani pidana, putri kandung mereka tersebut kembali kerumah dalam keadaan sehat walaffiat. ${ }^{3}$

3) Ada juga kasus salah tangkap yang menimpa salah satu mahasiswa perguruan tinggi swasta di daerah Yogyakarta yang bernama Halis Sabri. Ia ditangkap oleh Polisi hari jum'at tanggal 4 Juni 2010 dengan tuduhan sebagai pelaku pemerkosaan. $^{4}$

4) Kejadian salah tangkap pernah terjadi pada tahun 1974 yaitu kasus yang menimpa Sengkon dan Karta yang terpaksa harus menjalani pidana penjara bertahun-tahun atas suatu kejahatanpembunuhan yang tidak pernah sama sekali mereka lakukan. $^{5}$

Mengacu pada peristiwa-peristiwa tersebut diatas maka seorang penyidik didalam melakukan kewenanganya pada proses penyidikan tidak diperbolehkan melakukan penangkapan secara sewenang-wenang karena suatu penangkapan harus berdasarkan bukti awal yang cukup untuk menentukan apakah benar-benar seseorang telah melakukan suatu tidak pidana. Seseorang berdasarkan bukti awal yang tidak cukup untuk dikatakan telah malakukan suatu tindak pidana seyogyanya penyidik tidak diperkenankan melakukan suatu

\footnotetext{
${ }^{3}$ http://www.antaranews.com/print/69586/plnplans-to-allocate-rp62-tln-for-capex-nextyear,tanggal11 september 2011 ${ }^{4}$ http://www.zonaindo.com/2010/06/salah-tangkapmahasiswa-poldadiy.html,tanggal15September2010

${ }^{5}$ http://dekade80.blogspot.com/2009/04/sengkondan-karta-sebuah -ironi-keadilan.html, senin 12 september 2010
} 
penangkapan terhadap seseorang tersebut, bilamana penyidik melakukan hal tersebut berarti dia telah melakukan pelanggaran terhadap ketentuan yang diatur didalam KUHAP dan juga akan menimbulkan penderitaan bagi orang yang menjadi korban salah tangkap tersebut.

\section{METODE PENELITIAN}

Sesuai dengan judul dan materi yang di bahas maka penelitian ini adalah penelitian yuridis normatif. Metode penelitian Hukum normatif adalah suatu prosedur penelitian ilmiah untuk menemukan kebenaran berdasarkan logika keilmuan hukum dari sisi normatif. ${ }^{6}$ Oleh karena itu penelitian hukum ini difokuskan untuk mengkaji penelitian Hukum tentang perlindungan hukum terhadap korban salah tangkap dalam tindak Pidana menurut KUHAP.

Di dalam penelitian hukum terdapat beberapa pendekatan. Dengan pendekatan tersebut penelitian yang di gunakan adalah Yuridis normatif, maka pendekatan yang digunakan adalah pendekatan Perundang-Undang (statute approach) pendekatan tersebut melakukan pengkajian terhadap UndangUndang yang berhubungan dengan pokok permasalahan. $^{7}$ Selain itu juga pendekatan analisis (Analitical apptoach), pendekatan ini maksudnya menganalisa perlindungan hukum terhadap korban salah tangkap dalam tindak pidana menurut KUHAP.

Bahan hukum primer merupakan bahan hukum yang bersifat autoratif artinya mempunyai otoritas bahan hukum terdiri dari perundang-

${ }^{6}$ Johnny Ibrahim, Teori dan Metode Penelitian Hukum Normatif, cetakan ke enam, Bayumedia Publishing, Malang 2012. Hal 57

${ }^{7}$ Peter Mahmud Marzuki, Penelitian Hukum, Universitas Air Langga, Surabaya. 2005. Hlm. 96 undangan, catatan resmi, atau risalah dalam pembuatan Perundang-Undangan dan putusan Hakim. Adapun bahan hukum primer antara lain: UndangUndang Dasar Negara Indonesia Tahun 1945, Kitab Undang-Undang Hukum Pidana, Kitab Undang-Undang Hukum Acara Pidana, Undang-Undang nomor 2 Tahun 2002 tentang Kepolisian Negara Republik Indonesia, Peraturan Pemerintah (PP) Nomor 92 tahun 2015 tentang Pelaksanaan KUHAP

Bahan Hukum sekunder

Berupa semua publikasi tentang hukum yang bukan merupakan dokumendokumen resmi, yaitu berupa buku teks, kamus-kamus hukum, jurnal-jurnal hukum dasar, komentar-komentar atas putusan Pengadilan.

Bahan Hukum tersier adalah bahan hukum yang memberikan petunjuk atau penjelasan bermakna terhadap bahan hukum primer dan sekunder, seperti kamus hukum, ensiklopedia dan lain-lain. ${ }^{8}$

Baik bahan primer maupun bahan sekunder di kumpulkan berdasarkan topik permasalahan yang telah dirumuskan dan diklasifikasi menurut sumber dan hirarkinya untuk dikaji secara komprehensif.

Langkah-langkah yang berkaitan dengan pengolahan terhadap bahan hukum yang telah di kumpulkan untuk menjawab isu hukum yang telah di rumuskan dalam rumusan masalah. Tentu juga menyangkut kegiatan penalaran ilmiah terhadap bahan hukum yang di analisis, baik menggunakan induksi, deduksi, maupun abduksi.

\section{PEMBAHASAN}

Prosedur

penangkapan terhadap tersangka atau pelaku tindak 
pidana dalam KUHAP memiliki SOP (standard operating procedure) tertentu agar tindakan hukum bisa berjalan sesuai aturan. Jika pelaku hukum dalam hal ini adalah penegak hukum tidak mengindahkan prosedur hukum acara yang telah ada, maka banyak kemungkinan akan muncul perspektif bermacam-macam dari masyarakat. Dalam tahapan melakukan penangkapan terhadap sesorang yang diduga sebagai pelaku pidana, ada aturan-aturan atau unsur yang harus diperhatikan oleh penegak hukum. Sebab semua warga mendapatkan perlakuan yang sama dimata hukum. Contoh kecil unsur yang sangat penting adalah mengenai hak tersangka untuk memperoleh perlakuan manusiawi.

Dasar untuk prosedur penangkapan mengacu pada Kitab Undang-Undang Hukum Acara Pidana Bab V bagian kesatu Pasal 16 sampai Pasal 19 sebagai berikut: ${ }^{9}$

Di dalam Pasal 16 Kitab Undang-Undang Hukum Acara Pidana adalah prosedur pertama dalam melakukan penangkapan yakni:

1. Untuk kepentingan penyelidikan, penyelidik atas perintah penyidik berwenang melakukan penangkapan.

2. Untuk kepentingan penyidikan, penyidik dan penyidik pembantu berwenang melakukan penangkapan.

Mengenai alasan penangkapan atau syarat penangkapan tersirat dalam Pasal 17 yakni seorang tersangka diduga keras melakukan tindak pidana, dan dugaan yang kuat itu, didasarkan pada permulaan bukti yang cukup. Yang dimaksud dengan "bukti permulaan yang cukup" menurut penjelasan Pasal 17 ialah bukti

\footnotetext{
${ }^{9}$ M Karjadi dan R Soesilo, Op Cit, hlm 25-27
}

permulaan "untuk menduga" adanya tindak pidana sesuai dengan bunyi Pasal 1 butir 14. Selanjutnya penjelasan Pasal 17 menyatakan: "Pasal ini menunjukkan bahwa perintah penangkapan tidak dapat dilakukan dengan sewenang-wenang, tetapi ditujukan kepada mereka yang betulbetul melakukan tindak pidana”.

Membicarakan

cara pelaksanaan penangkapan, meliputi aspek pembahasan mengenai siapa petugas yang berwenang melakukan penangkapan serta syarat-syarat yang harus dipenuhi dalam melakukan penangkapan. Cara pelaksanaan penangkapan diatur dalam Pasal 18, menentukan:

1. Pelaksanaan tugas penangkapan dilakukan oleh petugas kepolisian Negara Republik Indonesia. Dari ketentuan ini, sudah jelas petugas mana yang boleh melakukan penangkapan. Jaksa penuntut umum tidak berwenang melakukan penangkapan kecuali dalam kedudukanya sebagai penyidik berdasar Pasal 248 ayat (2). Satpam atau Hansip tidak berwenang melakukan penangkapan, kecuali di dalam hal tertangkap tangan. Dalam hal tertangkap tangan "setiap orang berhak" melakukan penangkapan dan bagi orang yang mempunyai wewenanag dalam tugas ketertiban, ketentraman dan keamanan "wajib" menanagkap tersangka dalam hal tertangkap tangan.

2. Petugas yang diperintahkan melakukan penangkapan harus membawa "surat tugas penangkapan". Jika surat tugas penangkapan tidak ada, maka tersangka berhak menolak untuk mematuhi perintah penangkapan, 
karena surat tugas itu merupakan syarat formal yang bersifat “imperatif". Juga agar jangan terjadi penangkapan yang dilakukan oleh oknum yang tidak bertanggung jawab. Karena itu, demi untuk tegaknya kepastian serta untuk menghindari penyalahgunaan jabatan ataupun untuk menjaga ketertiban masyarakat dari pihak-pihak yang beritikad buruk.

3. Petugas memperlihatkan surat perintah penangkapan yang memberi penjelasan dan penegasan tentang:

a. Identitas tersangka, nama, umur, dan tempat tinggal, Jika ternyata identitas yang diterangkan dalam surat perintah penangkapan tidak sesuai,

bisa dianggap surat perintah itu "tidak berlaku" terhadap orang yang didatangi petugas.

b. Menjelaskan atau menyebut secara singkat alasan penangkapan.

c. Menjelaskan uraian singkat perkara kejahatan yang disangkakan terhadap tersangka.

d. Selanjutnya menyebut dengan terang di tempat mana pemeriksaan dilakukan.

Berdasarkan ketentuan Pasal 19 ayat (1) telah ditentukan batas waktu lamanya penangkapan, tidak boleh lebih dari "satu hari". Lewat dari satu hari berarti telah terjadi pelanggaran hukum, dan dengan sendirinya penangkapan dianggap "tidak sah". Konsekwensinya tersangka harus "dibebaskan demi hukum". Atau jika batas waktu itu dilanggar, tersangka, penasihat hukumnya, atau keluarganya dapat meminta pemeriksaan kepada Pra-peradilan tentang sah tidaknya penangkapandan sekaligus dapat menuntut ganti rugi.
Kasus salah tangkap adalah kasus pelanggaran HAM yang sistematis dan termasuk jenis kejahatan amat serius. Karena itu penanganannya harus bersifat extra ordinary. Para korban dapat pula menuntut para penegak hukum yang salah menghukum secara pidana dan perdata, misalnya karena penganiayaan sesuai dengan Pasal 351 KUHP dan Pasal 1365 KUHPerdata tentang perbuatan melawan hukum. Bagaimanapun dalam Negara demokrasi, keadilan dan kebenaran haruslah terbuka untuk setiap warga. Negara tanpa harus malu, tanpa mesti ditekan publik, wajib melaksanakan asas legalitas, yaitu memberi ganti rugi dan merehabilitasi nama baik warga yang menjadi korban salah tangkap. Adapun arti ganti rugi dan rehabilitasi dapat diuraikan sebagai berikut:

\section{Ganti Kerugian}

Ganti kerugian merupakan suatu upaya untuk mengembalikan hak-hak korban, yang karena kelalaian aparat penegak Hukum telah salah dalam menentukan seseorang untuk dijadikan sebagai tersangka atau terdakwa dalam suatu tindak Pidana (error in persona). Menurut Pasal 1 butir 22 KUHAP, yaitu: ${ }^{10}$

"Ganti kerugian adalah hak seseorang untuk mendapatkan pemenuhan atas tuntutannya yang berupa imbalan sejumlah uang karena ditangkap, ditahan, dituntut ataupun diadili tanpa alasan yang berdasarkan undang-undang atau karena kekeliruan mengenai orangnya

\footnotetext{
${ }^{10}$ Ibid, hlm 05
} 
atau hukum yang diterapkan menurut cara yang diatur dalam undang-undang ini."

Sedangkan dalam Pasal 99 KUHAP disebutkan bahwa kerugian itu berarti "biaya yang telah dikeluarkan". Pengertian ini termasuk atau meliputi diantaranya biaya pengobatan atau pemulihan cacat, dalam contoh konkrit membuat gigi palsu, pengecatan, dan lain sebagainya yang langsung diderita oleh orang lain yang dirugikan.

Kerusakan-kerusakan lain atau derita orang lain yang karena keadaan memaksa atau keadaan penyidik dapat pula diajukan permintaan ganti rugi yang digabungkan dengan permintaan orang lain tersebut ( Pasal 98 KUHAP). Namun demikian kebenaran materiil suatu kasus perkara harus diteliti dan dianalisa secara sungguh-sungguh, sehingga seseorang yang seharusnya menjadi saksi korban tidak akan dijadikan tersangka hanya karena tersangka yang sebenarnya telah melarikan diri. Hal ini wajib ditegakkan pula oleh penuntut umum dalam tahap pra penuntutan.

Pasal 101 KUHAP membuka kemungkinan Pengadilan Negeri memeriksa dan mengadili gugatan perdata atau ganti rugi sepanjang dalam KUHAP tidak diatur dengan kata lain yang dimaksud Pasal 101 KUHAP menyebutkan bahwa Pengadilan Negeri dapat memutus dan mengadili gugatan ganti rugi dalam ruang lingkup pidana, meliputi:

a. Ganti rugi menurut Pasal 77 jo Pasal 95 ayat (2).

b. Ganti rugi menurut Pasal 81 tentang akibat tidak sahnya penangkapan atau akibat sahnya penghentian penyidikan atau penuntutan.

c. Ganti rugi menurut Pasal 83 ayat (1) tentang adanya benda yang disita yang tidak termasuk dalam alat pembuktian.

d. Ganti rugi karena tindakan lain yaitu kerugian yang ditimbulkan oleh pemasukan rumah, penggeledahan dan penyitaan yang tidak sah menurut hukum.

e. Ganti rugi menurut Pasal 98 ayat 1 tentang ganti rugi oleh saksi korban atau orang lain dalam penggabungan atau orang lain yang tidak menjadi saksinya tetapi kerugianya timbul langsung oleh tindak pidana itu atau tindakan penyidik dalam melakukan upaya paksa.

f.Ganti rugi dengan acara pra peradilan.

g. Ganti rugi karena selisih lamanya penahanan melebihi lamanya pidana yang dijatuhkan karena mengenai perampasan kemerdekaan badan yang diperiksa dalam acara praperadilan.

h. Ganti rugi yang didasarkan pada Pasal 95 ayat (5) tentang pemeriksaan dan diadili mengikuti acara pra peradilan, mengikuti pula jika diputus bebas atau lepas dari segala tuntutan hukum yang telah memperoleh kekuatan hukum tetap, baik dari proses hukum atau dari proses peninjauan kembali.

Dengan demikian kita harus dapat memisahkan dan memahami untuk dapat menarik garis hukum mengenai apa yang dinamakan 'kerugian" menurut Kitab Undang- 
Undang Hukum Acara Pidana dan gugatan ganti rugi yang seharusnya diajukan ke Pengadilan Negeri yang menjadi perkara perdata.

$$
\text { Sedangkan Kementerian }
$$

Hukum dan HAM melansir Peraturan Pemerintah (PP) Nomor 92 tahun 2015 tentang Pelaksanaan KUHAP. Dalam aturan baru ini, korban ganti rugi salah tangkap maksimal mendapat ganti rugi Rp 600 juta, sebelumnya hanya Rp 3 juta. PP Nomor 92 tahun 2015 ini dilansir di website Kemenkum HAM atau peraturan.go.id, Jumat (11 Desember 2015). "Peraturan Pemerintah ini mulai berlaku pada tanggal diundangkan (8 Desember 2015)," demikian bunyi II PP Nomor 92 tahun 2015 tersebut. Aturan ganti rugi korban salah tangkap atau korban peradilan sesat tertuang dalam PP Nomor 27 tahun 1982 tentang Pelaksanaan KUHAP dan diundangkan oleh Presiden Soeharto pada 31 Desember 1983. Setelah itu, tidak ada satu pun rezim yang merevisi aturan tersebut. Pasca Soeharto tumbang, nilai ganti rugi ini tak pernah disentuh oleh pemerintah. Melihat hal ini, pada awal November 2015 Jokowi memerintahkan revisi aturan itu terkait ganti rugi korban salah tangkap. Dalam tempo satu bulan, revisi ini diundangkan. Tepat dengan Hari HAM Internasional tanggal 10 Desember 2015 lahir PP Nomor 92 tahun 2015 tentang Revisi PP 27 tentang Pelaksanaan KUHAP. Salah satu poin penting PP Nomor 92 tahun 2015 adalah merevisi ganti rugi salah tangkap, yaitu menjadi:

a. Ganti kerugian berdasarkan alasan sebagaimana dimaksud dalam Pasal 77 huruf $b$ dan Pasal 95 KUHAP paling sedikit Rp 500 ribu dan paling banyak Rp 100 juta (sebelumnya $\mathrm{Rp} 5$ ribu-Rp 1 juta).

b. Besarnya ganti kerugian berdasarkan alasan sebagaimana dimaksud dalam Pasal 95 KUHAP yang mengakibatkan luka berat atau cacat sehingga tidak bisa melakukan pekerjaan, besarnya ganti kerugian paling sedikit Rp 25 juta dan paling banyak Rp 300 juta (sebelumnya Rp 0-Rp 3 juta).

c. Besarnya ganti kerugian berdasarkan alasan sebagaimana dimaksud dalam Pasal 95 KUHAP yang mengakibatkan mati, besarnya ganti kerugian paling sedikit Rp 50 juta dan paling banyak Rp 600 juta (sebelumnya Rp 0-Rp 3 juta). Adapun untuk proses eksekusi, pemerintah wajib memberikan ganti rugi tersebut maksimal 14 hari sejak surat dari Ketua Pengadilan Negeri yang memberitahukan adanya ganti rugi tersebut, diterima pemerintah. Sebelumnya, tidak dibatasi waktunya hingga korban menerima gemerincing uang bisa bertahun-tahun lamanya.

\section{Rehabilitasi}

$\begin{array}{cc} & \text { Pengertian rehabilitasi } \\ \text { menurut Kitab Undang-Undang }\end{array}$ Hukum Acara Pidana terdapat dalam Pasal 97 KUHAP, sebelum Pasal itu pada Pasal 1 butir 23 terdapat pengertian tentang rehabilitasi yaitu: ${ }^{11}$

"Rehabilitasi adalah hak seseorang untuk mendapat pemulihan haknya dalam kemampuan, kedudukan dan

\footnotetext{
${ }^{11}$ Ibid, hlm 06
} 
harkat serta martabatnya yang diberikan pada tingkat penyidikan, penuntutan atau peradilan karena ditangkap, ditahan, dituntut atau pun diadili tanpa alasan yang berdasarkan Undang-Undang atau karena alasan kekeliruan mengenai orangnya atau hukum yang diterapkan menurut cara yang diatur dalam Undang-Undang ini”.

Dari pengertian diatas, senada dengan bunyi Pasal 97 KUHAP akan tetapi tidak dijelaskan secara mendetail dalam KUHAP adalah apakah rehabilitasi akibat putusan bebas atau lepas dari segala tuntutan hukum tersebut bersifat fakulatif (dituntut oleh terdakwa) atau bersifat imperatif (setiap kali Hakim memutus dan memperoleh kekuatan hukum tetap maka secara otomatis harus diberikan rehabilitasi). Hal ini semestinya diatur dalam aturan pelaksana KUHAP, kemudian sama halnya dengan tuntutan ganti rugi, pada proses rehabilitasi pun dibedakan antara perkara yang diajukan ke pengadilan negeri atau tidak. Dalam hal ini untuk perkara yang diajukan ke pengadilan negeri berlaku ketentuan Pasal 97 ayat 1 dan 2 KUHAP sebagai berikut: ${ }^{12}$

"Ayat 1 Seorang berhak memperoleh rehabilitasi apabila oleh pengadilan diputuskan bebas atau diputus lepas dan segala tuntutan hukum yang putusanya telah mempunyai kekuatan hukum tetap.

Ayat 2 Rehabilitasi tersebut diberikan dan dicantumkan sekaligus dalam putusan pengadilan sebagaimana dimaksud dalam ayat (1)"

Dengan kata lain maksud Pasal ini adalah memberikan hak kepada seseorang untuk

\footnotetext{
${ }^{12}$ Ibid, hlm 89
}

mendapatkan rehabilitasi jika ia oleh pengadilan diputus bebas atau diputus lepas dari segala tuntutan hukum yang putusannya telah mempunyai kekuatan hukum tetap. Sedangkan permintaan rehabilitasi ini harus diajukan jika perkaranya diperiksa di pengadilan negeri, maka rehabilitasi diajukan kepada ketua Hakim pengadilan negeri diperiksa oleh majelis pengadilan itu dan apabila rehabilitasi diberikan, maka hal itu dicantumkan sekaligus dalam putusan pengadilan. Akan tetapi jika perkara yang diperiksa itu tidak diajukan ke pengadilan negeri, hanya disampaikan ke tingkat penyidikan ataupun tingkat penuntutan saja, maka permintaan rehabilitasi harus diajukan kepada dan diputus oleh lembaga pra-peradilan.

Sebagaimana yang tidak diputus oleh Hakim pra-peradilan telah ditentukan dalam Pasal 77 huruf $b$ KUHAP, sebagaimana bunyinya di bawah ini:

"Ganti kerugian dan atau
rehabilitasi bagi seorang yang
perkara pidananya dihentikan
pada tingkat penyidikan atau
penuntutan"

3. Pelaksanaan Ganti Rugi Dan Rehabilitasi Diatur Dalam PP Nomor 27 Tahun 1983

\section{a. Ganti Rugi}

Cara pelaksanaan ganti rugi di atur dalam Bab IV Pasal 7 sampai dengan Pasal 11. Di dalam Pasal 7 yang berbunyi tuntutan ganti kerugian sebagaimana dimaksud dalam Pasal 95 KUHAP hanya dapat diajukan dalam tenggang waktu 3 (tiga) bulan sejak putusan pengadilan mempunyai kekuatan hukum 
tetap dan dalam hal tuntutan ganti kerugian tersebut diajukan terhadap perkara yang dihentikan pada tingkat penyidikan atau tingkat penuntutan sebagaimana dimaksud dalam Pasal 77 huruf $b$ KUHAP, maka jangka waktu 3 (tiga) bulan dihitung dari saat pemebritahuan penetapan praperadilan.

Pasal 8 Ganti kerugian dapat diberikan atas dasar pertimbangan hakim Dan dalam hal hakim mengabulkan atau menolak tuntutan ganti kerugian, maka alasan pemebrianatau penolakan tuntutan ganti kerugian dicantumkan dalam penetapan.

Pasal 9 Ganti kerugian berdasarkan alasan sebagaimana dimaksud dalam Pasal 77 huruf $b$ dan Pasal 95 KUHAP adalah berupa imbalan serendahrendahnya berjumlah Rp. 5000,(lima ribu rupiah) dan setinggitingginya Rp.100.000,- (seratus ribu rupiah). Apabila penagkapan, penahanan dan tindakan lain sebagaimana dimaksud dalam Pasal 95 KUHAP mengakibatkan yang bersangkutan sakit atau cacat sehingga tidak dapat melakukan pekerjaanatau mati, besarnya ganti kerugian berjumlah setinggi-tingginya Rp.3.000.000,- (tiga juta rupiah). Dan Pasal 10 yang berbunyi Petikan Penetapan mengenai ganti kerugian sebagaimana dimaksud dalam Pasal 8 diberikan kepada pemohon dalam waktu 3 (tiga) hari setelah penetapan diucapkan. Salinan Penetapan ganti kerugian sebagaimana diamksud dalam ayat (1) diberikan kepada penuntut umum, penyidik dan Direktorat Jenderal Anggaran dalam hal ini Kantor Perbendaharaan Negara setempat.
Dan yang terakhir Pasal 11 yaitu Pembayaran ganti kerugian dilakukan oleh Menteri Keuangan berdasarkan penetapan pengadilan sebagaimana dimaksud dalam Pasal 10. Tata cara pembayaran ganti kerugian diatur lebih lanjut oleh Menteri Keuangan.

b. Rehabilitasi

Sedangkan cara pelaksanaan Rehabilitasi di atur dalam Bab V Pasal 12 sampai dengan Pasal 15. Pasal 12 Permintaan rehabilitasi sebagaimana dimaksud dalamPasal 97 ayat (3) KUHAP diajukan oleh tersangka, keluarga atau kuasanya kepada pengadilan yang berwenang, selambatlambatnya dalam waktu 14 (empat belas) hari setelah putusan mengenai sah tidaknya penangkapan atau penahanan diberitahukan kepada pemohon.

$$
\text { Pasal } 13 \text { Petikan }
$$

penetapan pra-peradilan mengenai rehabilitasi disampaikan oleh panitera kepada pemohon. Salinan penetapan sebagaimana dimaksud dalam ayat (1) diberikan kepada penyidik dan penuntut umum yang menangani perkara tersebut. Salinan penetapan sebagaimana dimaksud dalam ayat disampaikan pula kepada instansi tempat bekerja yang bersangkutan dan kepada Ketua Rukun Warga di tempat tinggal yang bersangkutan.

Pasal 14 Amar putusan dari pengadilan mengenai rehabilitasi berbunyi sebagai berikut :"Memulihkan hak terdakwa dalam kemampuan, kedudukan dan harkat serta 
martabatnya". Dan Amar penetapan dari pra-peradilan mengenai rehabilitasi berbunyi sebagai berikut :"Memulihkan hak terdakwa dalam kemampuan, kedudukan dan harkat serta martabatnya".

Dan yang terakhir Pasal 15 Isi putusan atau penetapan rehabilitasi diumumkan oleh panitera dengan menempatkannya pada papan pengumuman pengadilan.

\section{KESIMPULAN}

1. Prosedur penangkapan yang dilakukan oleh penyidik telah sesuai dengan Kitab Undang-Undang Hukum Acara Pidana yaitu dengan mengacu pada Pasal 16 sampai dengan Pasal 19. Dalam Pasal 16 yang berbunyi penyelidik atas perintah penyidik berwenang melakukan penangkapan, Pasal 17 mengenai alasan dan syarat penangkapan, Pasal 18 mengenai cara pelaksanaan penangkapan, sedangkan Pasal 19 mengenai batas waktu lamanya penangkapan. Dalam Pasal-Pasal tersebut prosedur penangkapan yang penyidik lakukan melalui tahapan sebagai berikut: pembuatan surat perintah penangkapan, penangkapan tersangka, dan penyidikan tersangka di kantor polisi.

2. Perlindungan hukum bagi korban salah tangkap yakni dengan adanya pemberian ganti kerugian dan rehabilitasi sesuai dengan Pasal 95 dan 97 KUHAP. Penyidik yang melakukan kesalahan dalam penangkapan mendasari pemahaman tersebut sesuai dengan ketentuan KUHAP. Maka penyidik memberikan ganti rugi dalam bentuk materi'il dan immateri'il. Materi'il yang berupa pemberian uang sedangkan immateri'il berupa pemulihan kedudukan, nama baik, harkat serta martabatnya.

\section{SARAN}

1. Sebelum melakukan penangkapan terhadap seseorang, penyidik harus menyelidiki lebih dalam lagi tentang kasus yang sedang ditanganinya, agar tidak melakukan salah tangkap kepada seseorang dan dalam proses pemeriksaan terhadap seseorang yang diduga telah melakukan kejahatan, penyidik harus menggunakan metode-metode yang tepat untuk mencari keterangan dari seseorang tersebut, dan dalam metode-metode yang digunakan oleh penyidik supaya penyidik tidak melanggar Hak Asasi Manusia dan tetap mengedepankan prosedur penyidikan yang berlaku.

2. Jika terbukti penyidik melakukan salah tangkap, ganti kerugian yang diberikan oleh penyidik kepada korban salah tangkap harus sesuai dengan aturan yang ada yaitu ganti kerugian berbentuk materi dan immaterial dan rehabilitasi yang diberikan oleh penyidik harus dilakukan secara total menyeluruh.

\section{DAFTAR PUSTAKA}

Andi Hamzah, Asas-Asas Hukum Pidana, Jakarta: PT. Rineka Cipta, Tahun 2004.

Johnny Ibrahim, Teori dan Metode Penelitian Hukum Normatif, cetakan ke enam, Bayumedia Publishing, Malang Tahun 2012. 
Moeljatno, Asas-Asas Hukum Pidana, Jakarta: Bina Aksara, Tahun 1987.

M Yahya Harahap, Pembahasan Permasalahan Dan Penerapan KUHAP Penyidikan dan Penuntutan, Sinar Grafika, Jakarta tahun 2009.

Peter Mahmud Marzuki. Penelitian Hukum. Universitas Air Langga, Surabaya, Tahun 2005.

Satjipto Rahardjo, Ilmu Hukum, Bandung: PT. Citra Aditya Bakti, Tahun 2000.

Sulchan Yasyin, Kamus Pintar Bahasa Indonesia.

PERATURAN

PERUNDANG

UNDANGAN

Undang-Undang Dasar Negar Republik Indonesia Tahun 1945

Kitab Undang-Undang Hukum Pidana (KUHP)

Undang-Undang nomor 8 Tahun 1981 tentang Kitab Undang-Undang Hukum Acara Pidana (KUHAP)

Undang-Undang nomor 2 Tahun 2002 tentang Kepolisian Negara Republik Indonesia

Peraturan Pemerintah (PP) Nomor 92 tahun 2015 tentang Pelaksanaan KUHAP

JURNAL DAN ARTIKEL

Sugeng, "Perlindungan Hukum Korban Salah Tangkap", Makalah, Fakultas Hukum Universitas Pawyatan Daha

https://m.tempo.co/read/video/2016/03/ 28/4259/pelajar-korban-salah-tangkapini-ditembak-dan-dianiaya-polisi http://www.antaranews.com/print/6958 6/pln-plans-to-allocate-rp62-tln-for- capex-next-year,tanggal11 september 2011 http://www.zonaindo.com/2010/06/sala h-tangkap-mahasiswa-poldadiy.html,tanggal15September2010 http://dekade80.blogspot.com/2009/04/s engkon-dan-karta-sebuah-ironikeadilan. html, senin 12 september 2010 http://www.damang.web.id/2011/07/put usan-praperadilan-terhadap.html? $\mathrm{m}=1$ http://www.pikiranrakyat.com/prprint.php?mib=beritadetai $1 \& \mathrm{id}=41587$ http://www.wikimu.com/News/Print.as px?id=10783 